\title{
Analisis Kualitas Sifat Fisik Tanah pada Lahan Subak di Bali
}

\section{Analysis of Soil Quality as a Parameter of Subak System as Environmental Services}

\author{
Widyalis Rani Tamara, Sumiyati*, I Made Anom Sutrisna Wijaya \\ Program Studi Teknik Pertanian, Fakultas Teknologi Pertanian Universitas Udayana, Badung, Bali, Indonesia \\ *email: sumiyati@unud.ac.id
}

\begin{abstract}
Abstrak
Subak merupakan organisasi kemasyarakatan yang ada di Bali yang khusus mengatur sistem pembagian air secara tradisional di sawah untuk bercocok tanam padi. Dengan perkembangan jaman yang pesat ini, keberadaan subak terancam karena adanya alih fungsi lahan ke penggunaan lain di luar sektor pertanian yang menyebabkan ruang terbuka hijau akan semakin berkurang. Jasa lingkungan merupakan jasa yang diberikan oleh fungsi ekosistem yang memiliki manfaat langsung maupun tidak langsung terhadap kehidupan manusia. Penelitian ini bertujuan untuk menganalisis perubahan kualitas tanah yang ada di subak pada saat sebelum tanam dan sesudah panen untuk melihat kontribusi subak terhadap lingkungan. Metode yang digunakan yaitu metode survei dan uji laboratorium untuk menganalisis sifat fisik tanah. Pengambilan sampel dilakukan secara random sampling, dengan lokasi subak sampel yaitu Subak Kerdung, Subak Jatiluwih dan Subak Lotunduh. Kualitas tanah dinilai dengan menggunakan teknik penilaian berdasakan parameter fisik tanah. Parameter yang diamati yaitu sifat fisik tanah yang meliputi tekstur, porositas, kapasitas lapang, berat jenis dan berat volume. Hasil analisis menunjukkan perubahan kualitas tanah pada lahan subak menjadi lebih baik. Kontribusi subak dari segi sifat fisik tanah, yaitu dapat meningkatkan porositas dan menurunkan nilai berat volume tanah subak. Porositas dari Subak Jatiluwih pada fase sebelum tanam adalah 56,27\% dan pada fase sesudah panen meningkat menjadi 66,91\%. Penurunan berat volume terbaik terdapat pada Subak Jatiluwih yaitu pada fase sebelum tanam $1,05 \mathrm{~g} / \mathrm{cm}^{3}$ kemudian menurun menjadi $0,92 \mathrm{~g} / \mathrm{cm}^{3}$ pada fase setelah panen. Jasa lingkungan dari sistem subak yaitu mampu menjaga dan meningkatkan kualitas tanah dengan adanya aktivitas dan pengolahan tanah.
\end{abstract}

Kata kunci: : jasa lingkungan, kualitas tanah, parameter fisik tanah, subak

\begin{abstract}
Subak is a social organization in Bali that specifically regulates traditional water distribution system to grow rice. With the rapid development of this time, the existence of subak is threatened because of the conversion of land to other uses outside the agricultural sector which causes open green space to be increasingly reduce. Environmental services are the services provided by the ecosystem functions that have direct and indirect benefits to human welfare. This research analyzed to changes in soil quality in subak, in the conditions before planting and after harvest an to show subak contribution to the environment. This study used survey method, physical soil test in the laboratory. The samples were taken by random sampling, from Subak Kerdung, Subak Jatiluwih and Subak Lodtunduh. The soil qualities were assessed using scoring technique based on the physical parameters. The soil physical parameters observed were texture, porosity, field capacity, bulk density and particle density. The result of research showed that the change in soil quality on the subak land was be better. Contribution of subak can be seen from the physical soil parameters, that is increased porosity and decreased bulk density of subak. Subak Jatiluwih in the before planting phased had porosity of $56,27 \%$ and then $66,91 \%$ after harvest phase. The best change of bulk density in Subak Jatiluwih in the before planting phase is $1,05 \mathrm{~g} / \mathrm{cm}^{3}$ and then decreased to $0,92 \mathrm{~g} / \mathrm{cm}^{3}$ after harvest phase. Environmental services of subak system is able to maintain and improve the quality of the soil through the ability to cultivate the soil.
\end{abstract}

Keyword: enviromental services, physical soil parameters, soil quality, subak

\section{PENDAHULUAN}

Dengan perkembangan jaman yang pesat seperti saat ini, eksistensi subak semakin terancam karena adanya alih fungsi lahan sawah beririgasi ke penggunaan lain diluar sektor pertanian. Banyak sekali lahan sawah yang dijadikan tempat pembangunan diluar sektor pertanian seperti pembangunan vila dan perumahan. Pada tahun 2011-2016, menurut data Dinas Tanaman Pangan, Hortikultura, dan Perkebunan Provinsi Bali, rata-rata alih fungsi lahan pertanian sekitar 550 hektar per tahun. 
Menurut Windia (et. al, 2005) subak merupakan organisasi pengairan tradisional bidang pertanian yang berdasarkan atas seni dan budaya serta diwarisi secara turun temurun oleh masyarakat di Bali. Subak adalah organisasi kemasyarakatan yang khusus mengatur sistem pengairan sawah yang digunakan dalam bercocok tanam padi di Bali. Subak tidak hanya terbatas pada organisasi pengelolaan air dan jaringan irigasi, namun berkaitan erat dengan ekosistem dan berfungsi sebagai pelestarian lingkungan. Vegetasi yang terdapat pada lingkungan dan lahan subak sangat berperan sebagai penyedia oksigen dan penyaring udara bersih. Bila lahan-lahan sawah terus berkurang bahkan habis, maka akan sirna pula berbagai manfaat yang diperoleh dari fungsi sistem subak selama ini (Sutawan, 2005).

Kualitas tanah adalah kapasitas tanah yang berfungsi mempertahankan produktivitas tanaman, mempertahankan dan menjaga ketersediaan air serta mendukung kegiatan manusia. Kualitas tanah yang baik akan mendukung kerja fungsi tanah sebagai media pertumbuhan tanaman, mengatur dan membagi aliran air serta dapat menjaga lingkungan yang baik pula (Cahyadewi et. al, 2016). Dalam rangka optimalisasi sumberdaya khususnya tanah, maka adanya lahan pertanian khususnya keberadaan subak merupakan salah satu komponen yang sangat penting. Keberhasilan pembangunan pertanian, khususnya pertanian padi sawah sangat ditentukan oleh kualitas tanah. Dengan adanya aktivitas di lahan pertanian dapat memberikan dampak positif terhadap kandungan unsur hara tanah. Tanah memiliki manfaat sebagai media penyerap dan penyimpan air. Kondisi tersebut menunjukkan pentingnya tanah pada sektor pertanian sebagai suatu faktor yang mempengaruhi jasa lingkungan.

Jasa lingkungan merupakan jasa yang diberikan oleh fungsi ekosistem alami maupun buatan yang nilai dan manfaatnya dapat dirasakan secara langsung maupun tidak langsung oleh para pemangku kepentingan (stakeholder) dalam rangka membantu memelihara dan meningkatkan kualitas lingkungan dan kehidupan masyarakat dalam mewujudkan pengelolaan ekosistem secara berkelanjutan (Suprayitno, 2008). Jasa lingkungan memiliki beberapa fungsi diantaranya sebagai jasa penyediaan, jasa pengaturan, jasa kultural dan jasa pendukung (Wunder, 2005).

Tujuan dari penelitian ini adalah untuk mengetahui perubahan kualitas tanah yang ada pada sistem subak sebelum dan sesudah tanam dan untuk mengetahui kontribusi subak terhadap lingkungan berdasarkan analisis kualitas sifat fisik tanah. Kualitas tanah diukur berdasakan pengamatan kondisi dinamis indikator- indikator kualitas tanah. Indikator kualitas tanah adalah sifat dan karakteristik atau proses fisika tanah yang dapat menggambarkan kondisi tanah. Komponen tanah yang terdiri dari bahan padatan, air dan udara merupakan sumberdaya alam utama yang sangat mempengaruhi kehidupan. Tanah yang memiliki fungsi utama sebagai tempat tumbuh dan berproduksi tanaman. Kemampuan tanah sebagai media tumbuh akan optimal jika didukung oleh sifat fisika, kimia dan biologi yang baik, biasanya menunjukkan tingkat kesuburan tanah dan dapat menyangga lingkungan yang baik pula.

\section{METODE}

\section{Tempat dan Waktu Penelitian}

Pengambilan sampel dilakukan di 3 subak yaitu, Subak Kerdung yang berlokasi di Banjar Pitik, Pedungan, Kecamatan Denpasar Selatan, Subak Jatiluwih yang berlokasi di Kecamatan Penebel, Kabupaten Tabanan dan Subak Lotunduh yang berlokasi di Desa Singakerta Kecamatan Singapadu, Kabupaten Gianyar. Analisis sempel dilaksanakan di Laboratorium Pengelolaan Sumber Daya Alam Fakultas Teknologi Pertanian, dan Laboratorium Tanah dan Lingkungan Fakultas Pertanian Universitas Udayana. Penelitian ini dilakukan dari bulan Maret sampai bulan Agustus 2019.

\section{Alat dan Bahan Penelitian}

Alat- alat yang digunakan dalam penelitian ini antara lain, ring soil sampler, plastik, penggaris, tabung reaksi, erlenmeyer, pipet $1 \mathrm{ml}$, timbangan analitik, oven.

\section{Rancangan Penelitian}

Penelitian ini menggunakan metode deskriptif eksploratif yang pengamatannya dilakukan melalui pengamatan dilapangan dengan batas amatan adalah areal persawahan dan didukung hasil analisis laboratorium. Sampel tanah yang diamati terdiri dari sifat fisika tanah (tekstur, porositas, berat jenis, berat volume dan kapasitas lapang). Pengambilan sampel tanah dilakukan sebelum tanam dan setelah panen, untuk kemudian dianalisis di labolatorium. Deskripsi penialaian kualitas tanah dilakukan dengan cara pengukuran indikator kualitas tanah menggunakan parameter penilaian berdasarkan metode Lal (1994).

\section{Deskripsi Penilaian Kualitas Tanah}

Pengkriteriaan faktor pembatas dan pembobotan relatif indikator kualitas tanah menurut Lal (1994) disajikan pada Tabel 2.

\section{Metode penelitian}

Adapun metode yang digunakan untuk menganalisis kualitas tanah yaitu: 
Tabel 1. Parameter dan Metode Analisis Kualitas Tanah (Lal,1994)

\begin{tabular}{l|ll} 
Parameter & Satuan & Metode \\
Sifat Fisik & & \\
\hline 1. Tekstur & $\%$ & Pipet \\
2. Berat Volume & $\mathrm{g} / \mathrm{cm}^{3}$ & Gravimetri \\
3. Berat Jenis & $\mathrm{g} / \mathrm{cm}^{3}$ & Ring sampler \\
4.Kapasitas Lapang & $\%$ & Drainase bebas \\
5. Porositas & $\%$ & Ring sampler \\
\hline
\end{tabular}

Sumber: Balai Penelitian Tanah (LPT, 1979)

Tabel 2. Faktor pembatas dan bobot relatif indikator kualitas tanah

\begin{tabular}{l|c|c|c|c|c} 
Indikator & \multicolumn{5}{c}{ Faktor pembatas dan bobot relatif } \\
& Tanpa & Ringan & Sedang & Berat & Ekstrim \\
& 1 & 2 & 3 & 4 & 5 \\
\hline Tekstur tanah (\%) & $\mathrm{L}$ & $\mathrm{SiL}, \mathrm{Si}, \mathrm{SiCL}$ & $\mathrm{CL}, \mathrm{SL}$ & $\mathrm{SiC}, \mathrm{LS}$ & $\mathrm{S}, \mathrm{C}$ \\
Porositas (\%) & $60-70$ & $50-60$ & $30-50$ & $20-30$ & $<20$ \\
Kadar Air Kapasitas & $>30$ & $20-30$ & $8-20$ & $2-8$ & $<2$ \\
Lapang (\%) & & & & & \\
Berat volume $\left(\mathrm{g} / \mathrm{cm}^{3}\right)$ & $<1,3$ & $1,3-1,4$ & $1,5-1,6$ & $1,6-1,7$ & $>1,8$ \\
\hline
\end{tabular}

(sumber: Lal, 1994)

Keterangan: $\mathrm{L}=$ Loam (Lempung); $\mathrm{Si}=\operatorname{silt}(\mathrm{debu}) ; \mathrm{S}=$ sand (pasir); $\mathrm{C}=$ clay (liat)

\section{HASIL DAN PEMBAHASAN}

Dalam menilai atau membandingkan kualitas tanah sebagai parameter jasa lingkungan, maka setiap parameter sifat fisika tanah harus diketahui. Semua sifat tersebut dapat digunakan untuk menentukan apakah tanah tersebut mampu menyediakan hara yang dibutuhkan oleh tanaman dan mampu memberikan jasa lingkungan.

\section{Hasil Analisis Parameter Fisik Tanah}

Parameter fisik yang diamati adalah tekstur tanah, porositas, kapasitas lapang, Bulk Density atau berat volume tanah (BV) dan Particle Density atau berat jenis (BJ).

\section{Tekstur Tanah}

Tekstur adalah perbandingan relatif antara fraksi pasir, debu dan liat. Tekstur tanah merupakan penentu dari parameter fisik tanah yang lainnya. Tekstur tanah pada masing - masing subak sampel, pada Subak Kerdung memiliki tekstur tanah lempung/loam (L), Subak Jatiluwih memiliki tekstur tanah lempung berliat/clay loam (CL) dan pada Subak Lotunduh memiliki tekstur tanah lempung liat berdebu/ silk clay loam (SiCL).

Berdasarkan tabel hasil analisis tekstur tanah, fraksi pasir pada Subak Kerdung memiliki persentase peningkatan lebih tinggi dari pada subak sampel yang lain. Hal ini disebabkan karena adanya pemberian pupuk silika $\left(\mathrm{SiO}_{2}\right)$ pada lahan di subak tersebut. Secara umum fraksi pasir terbentuk dari mineral kuarsa silika (Tangketasik, 2012).

Fraksi debu pada Subak Jatiluwih memiliki persentase penurunan lebih tinggi dari pada subak sampel yang lain. Hal ini disebabkan karena tanahtanah yang mengandung debu lebih banyak mudah terbawa oleh air. Debu sulit membentuk agregat yang mantap dan berukuran relative kecil sehingga mudah dihanyutkan aliran permukaan seperti air irigasi (Soniari, 2016). Fraksi liat pada Subak Jatiluwih meningkat lebih tinggi dari pada sampel subak yang lain. Hal ini disebabkan karena di Subak Jatiluwih dominan menggunakan pupuk organik dan pupuk kandang.

Selain itu pada Subak Jatiluwih telah lama menerapkan pembenaman jerami pada lahan sawah. Sesuai dengan pernyataan Foth (1998) bahwa terdapat kecenderungan suatu kolerasi anatara kandungan liat tanah dengan kandungan bahan organik, semakin besar kandungan liat maka semakin tinggi kandungan bahan organik tanah.

Tabel 4. Persentase tekstur tanah subak 


\begin{tabular}{llll}
\hline Nama Subak & Fraksi- fraksi & Sebelum Tanam & Setelah Panen \\
\hline Subak Kerdung & Pasir (\%) & 26,30 & 26,50 \\
& Debu (\%) & 34,04 & 33,78 \\
& Liat (\%) & 39,66 & 39,72 \\
& Kelas Tesktur & Lempung & Lempung \\
Subak Jatiluwih & Pasir (\%) & 23,12 & 23,13 \\
& Debu (\%) & 32,53 & 32,20 \\
& Liat (\%) & 44,35 & 44,68 \\
Subak Lotunduh & Kelas Tesktur & Lempung berliat & Lempung berliat \\
& Pasir (\%) & 20,57 & 20,58 \\
& Debu (\%) & 45,06 & 44,83 \\
& Liat (\%) & 34,37 & 34,59 \\
& Kelas Tesktur & Lempung liat berdebu & Lempung liat berdebu \\
\hline
\end{tabular}

Porositas (\%)

Berdasarkan hasil analisis porositas dari sampel tanah pada masing- masing subak pada saat sebelum tanam dan sesudah panen mengalami peningkatan. Adapun porositas tanah ketiga subak sampel pada sebelum tanam dan sesudah panen dapat dilihat pada Gambar 1.

Perubahan porositas tanah pada masing-masing sampel tanah subak tergolong tanpa faktor pembatas karena pada tekstur tanah pada lahan subak tersebut dominan mengandung liat yang tinggi. Hal ini sejalan dengan pernyataan Hardjowigeno (2003) dimana tanah dengan tekstur liat dominan mengandung pori mikro, sehingga mudah untuk menahan dan mengikat air.

\section{Kapasitas Lapang (\%)}

Berdasarkan hasil analisis di labolatorium menunjukkan kapasitas lapang dari sampel tanah pada masingmasing subak pada saat sebelum tanam dan sesudah panen mengalami peningkatan. Adapun kapasitas lapang ketiga subak sampel pada sebelum tanam dan sesudah panen dapat dilihat pada Gambar 2.

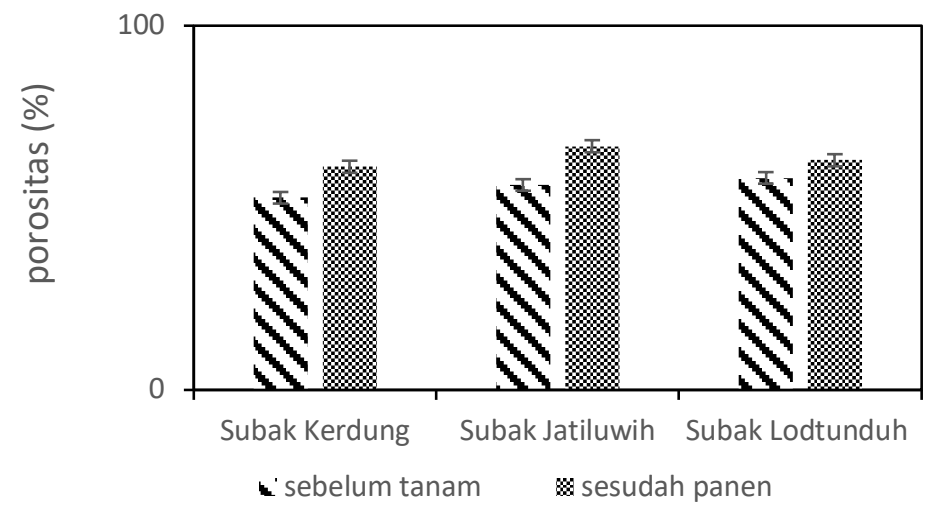

Gambar 1. Grafik perubahan porositas tanah subak

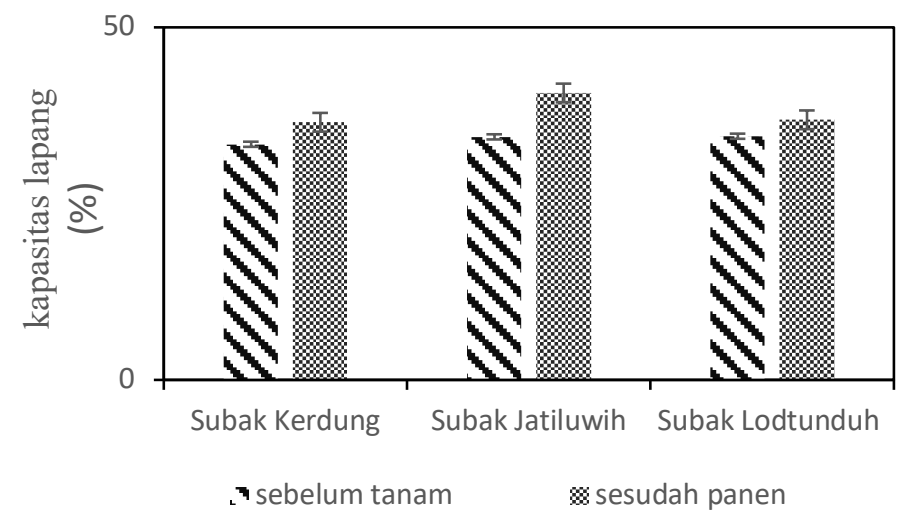

Gambar 2. Grafik perubahan kapasitas lapang tanah subak 
Berdasarkan Gambar 2, pada sampel tanah dari Subak Jatiluwih memiliki kapasitas lapang yang lebih tinggi dari pada subak sampel yang lain. Hal ini disebakan karena tanah pada subak tersebut mengandung bahan organik yang tinggi. Sesuai dengan pernyataan Baskoro dan Tarigan (2007), dimana makin tinggi bahan organik tanah, air yang tersedia makin tinggi dan makin kasar tekstur tanah, air yang tersedia makin rendah serta, makin besar ukuran pori tanah maka makin mudah air dilepaskan.

\section{Berat Jenis Kamba / Bulk Density $\left(\mathrm{g} / \mathrm{cm}^{3}\right)$}

Berdasarkan hasil analisis sifat fisik tanah berat jenis kamba (bulk density) sampel tanah dari Subak Kerdung, Subak Jatiluwih dan Subak Lotunduh sebelum tanam dan sesudah panen mengalami penurunan, yang menandakan bahwa adanya aktivitas pengolahan tanah yang baik. Adapun perubahan dari berat volume pada tiap subak dapat dilihat pada Gambar 3.
Pada ketiga subak, berat bulk density tanah pada Subak Jatiluwih mengalami penurunan berat yang lebih tinggi, hal ini disebabkan penggunaan dan pemberian bahan organik dan adanya pengembalian biomassa jerami yang tidak dibakar seperti pada umumnya melainkan dijadikan sebagai pupuk dengan cara dibenamkan dalam tanah. Menurut Buckman dan Brady (1992) pengolahan tanah dan pemberian bahan pengkondisian tanah (seperti bahan organik), pupuk organik (pupuk kandang, kompos) merupakan salah satu cara untuk menurunkan berat volume tanah (bulk density), sehingga tanah lebih bergumpal dan menjadi longgar.

\section{Berat Jenis Nyata / Particle Density $\left(\mathrm{g} / \mathrm{cm}^{3}\right)$}

Berdasarkan hasil analisis berat jenis tanah dari tiap sampel subak pada saat sebelum tanam dan setelah panen mengalami peningkatan. Hal tersebut disebabkan tanah pada subak-subak tersebut mengandung kandungan liat yang relatif tinggi.

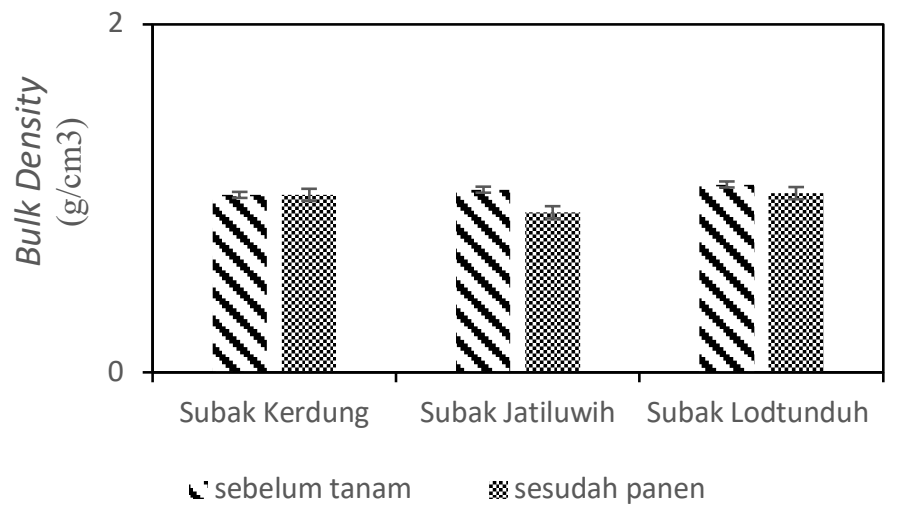

Gambar 3. Grafik perubahan bulk density tanah subak

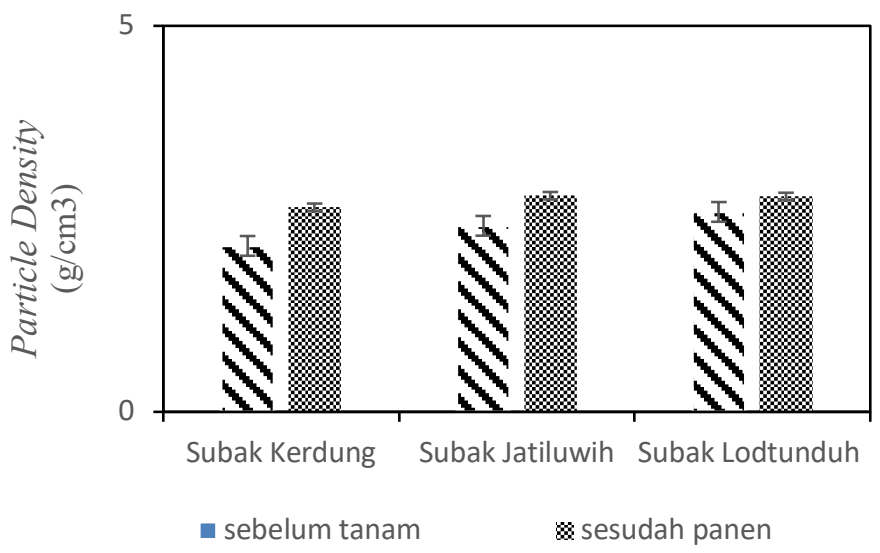

Gambar 4. Grafik perubahan particle density pada tanah subak

Berdasarkan grafik diatas dapat dilihat berat jenis tanah pada Subak Jatiluwih memiliki berat jenis yang relatif tinggi dibandingkan subak sampel yang lain. Sarief (1986) menyatakan bahwa nilai berat jenis tanah dapat dipengaruhi oleh berbagai faktor diantaranya pengolahan tanah, bahan organik, pemadatan tanah baik oleh air hujan maupun alat pertanian, tekstur dan kandungan air. 


\section{KESIMPULAN DAN SARAN}

\section{Kesimpulan}

Berdasarkan hasil dan pembahasan yang dilakukan, maka dapat diambil kesimpulan sebagai berikut: perubahan kualitas tanah dengan adanya aktivitas pengolahan tanah pada sistem subak pada saat sebelum tanam dan sesudah panen dapat menjaga dan meningkatkan kualitas tanah tersebut. Perubahan sifat fisik tanah yang meningkatkan kualitas tanah adalah meningkatnya nilai porositas dan berat volume tanah. Kontribusi subak terhadap lingkungan berdasarkan kualitas sifat fisik dan kimia tanah dapat memberikan jasa lingkungan yang positif melalui adanya aktivitas pengolahan tanah. Dari segi kualitas fisik tanah, subak mampu berperan meningkatkan porositas dan menurunkan berat volume tanah tanah sehingga tanah memiliki kemampuan dalam mengikat air

\section{Saran}

Berdasarkan hasil penelitian yang telah dilaksanakan, adapun saran yang dapat diberikan adalah perlu dilakukannya penggunaan pupuk organik dan pupuk kandang yang maksimal pada lahan subak untuk memperbaiki dan meningkatkan kualitas tanah.

\section{DAFTAR PUSTAKA}

Abdul Rahman Arinong, 2013. Fosfor Tanah. Tersedia di www.stppgowa.ac.id. (diakses: 10/08/2019).

Bukcman, H. O. dan N. C. Brady. 1992. Ilmu Tanah. Terjemahan Soegiman. Bhatara Karya Aksara. Jakarta

Cahyadewi, P. E., Diara, I. W., \& Arthagama, I. D. M. (2016). Uji Kualitas Tanah dan Arahan Pengelolaannya Pada Budidaya Padi Sawah di Subak Jatiluwih, Penebel, Tabanan. E-Jurnal Agroekoteknologi Tropika (Journal of Tropical Agroecotechnology), 232-242.

Damanik, M. M. B., Hasibuan, B. E., Fauzi, S., \& Hanum, H. (2011). Kesuburan Tanah dan Pemupukan. Universitas Sumatera Utara Press, Medan.

Foth, H.D. 1998. Dasar-dasar Ilmu tanah. Gadjah Mada University Press. Yogyakarta. 782 p.

Hanudin, E., Matsue, N., \& Henmi, T. (2000). Change in charge characteristics of allophane with adsorption of low molecular weight organic acids. Clay science, 11(3), 243-255.
Hardjowigeno, S. (2003). Ilmu Tanah Ultisol. Edisi Baru. Akademika Pressindo, Jakarta.

Lal, R. (1994). Methods and Guidelines for Assessing Sustainable use of Soil and Water Resources in the Tropics. Ohio State Univ., Ohio (EUA). Dept. of Agronomy Soil Management Support Services, Washington, DC, (EUA).

Odjak, M. (1992). Effect of Potassium Fertilizer in Increasing Quality and Quantity of Crop Yield. Dalam Peranan Kalium dalam Pemupukan Berimbang untuk Mempercepat Swasembada Pangan. Prosiding Seminar Nasional Kalium. Jakarta (Vol. 4, pp. 94-104).

Pangan, D. P. T. (2011). Hortikultura (DPTPH) Bali. 2007. Fenomena dan Strategi Kebijakan Pemerintah Daerah dalam Pengentalian Konversi Lahan Sawah di Provinsi Bali dan Nusa Tenggara Barat.

Rohmah G. 2014. Ecological and Psychological Carrying Capacity of Tourism in Themepark, Case Study: Taman Wisata Matahari Cisarua Bogor [tesis]. Bogor (ID) : Institut Pertanian Bogor.

Sarief, E. S. (1986). Kesuburan dan pemupukan tanah pertanian. Pustaka Buana. Bandung, 182.

Suprayitno. (2008). Teknik Pemanfaatan Jasa Lingkungan dan Wisata Alam. Bogor. Departemen Kehutanan Pusat DIKLAT Kehutanan.

Sutanto, R. (2005). Dasar-Dasar Ilmu Tanah, Konsep dan Kenyataan. Kanisius.

Sutawan, N. (2005). Subak Menghadapi Tantangan Globalisasi. Revitalisasi Subak dalam Memasuki Era Globalisasi. Andi: Yogyakarta.

Tangketasik, A., Wikarniti, N. M., Soniari, N. N., \& Narka, I. W. (2012). Kadar bahan organik tanah pada tanah sawah dan tegalan di Bali serta hubungannya dengan tekstur tanah. Agrotrop: Journal on Agriculture Science, 2(2).

Wigati, E. S., \& Syukur, A. (2006). Pengaruh Takaran Bahan Organik dan Tingkat Kelengasan Tanah Terhadap Serapan Fosfor oleh Kacang Tunggak di Tanah Pasir Pantai. Jurnal Ilmu Tanah dan Lingkungan, 6(2006).

Windia, W., Pusposutardjo, S., Sutawan, N., Sudira, P., \& Arif, S. S. (2005). Sistem Irigasi Subak dengan Landasan Tri Hita Karana (THK) sebagai Teknologi Sepadan dalam Pertanian Beririgasi.SOCA (Socio-Economic of Agriculturre and Agribusiness). 